\title{
Elementary and Secondary Education in Iowa, 1890-1900: A Time of Awakening
}

\author{
Part I
}

KEACH JOHNSON

SUPERINTENDENT James McNaughton of Council Bluffs, the president of the Iowa State Teachers' Association, opened the association's thirty-sixth annual meeting on December 30, 1890 on a somber note. "With the increasing density of population and the concentration of wealth that is rapidly coming upon us as a nation," McNaughton warned, "there is reason for grave fears that a crisis is near at hand that will put to test all the wisdom and forbearance of this people to avert disaster." The emerging industrial order in the United States and the world had produced a series of evils that threatened the promise of American life. Extremes of great wealth and bitter poverty bred social tension and class conflict. Mechanization of production stifled the creative impulse of the craftsman, reducing him to the status of a mechanical manipulator of machines. Domination by powerful corporations and trusts drove small manufacturers and tradesmen out of business, forcing the poor but ambitious boy to enter the "overworked professions" or to become the "hireling" of a great corporation "at wages which he has no voice in establishing." Development of a system of artificial vocational distinctions honored the orator, the scholar, and the 
scientist but had little regard for the manual laborer. And finally, commercialization of politics elevated millionaires to high office and threatened to transform the nature of American government from a representative democracy to an "offensive oligarchy." 1

To prepare young Americans to cope with the complexity of modern industrialism for which the experience of the past offered few precedents and little guidance, McNaughton declared that American educators must break new ground. They should stop imitating European models and develop a distinctively American system of education based on new goals, methods, and responsibilities. They must free American schools from their "bondage" to the "musty curricula of the middle ages," leave Greek and possibly Latin to the classicists, turn from memorization for the sake of discipline to the expression of thought for its own sake, study the growth of science and its application to business, and cultivate a better understanding of the relationship of man and nature. Educators must recognize the obligation of the American public school system, "the only institution founded by man" that was open to the children of all classes on equal terms, to teach good citizenship, social equality, and the dignity and worth of all forms of useful labor. They should institute instruction in political science as soon as children had learned the three R's, not merely to teach the duties and titles of public officials, so frequently the current practice, but to teach the basic principles of government, the duties and rights of individual citizens, and methods of righting wrongs and achieving reforms. Intelligent and responsible citizenship was "the only hope left to maintain free institutions and good government." 2

McNaughton's address is a striking example of the ambivalence felt by many Americans in the 1890s: fear that onrushing industrialism would subvert American democracy on the one hand, and on the other faith in the ability of the American peo-

${ }^{1}$ Proceedings of the Iowa State Teacher's Association, Thirty-sixth Annual Meeting, December 30, 1890-January 2, 1891, (n.p., n.d.), 23-25, 26-27, 28. Hereafter cited as Proceedings, IaSTA, December 30, 1890-January 2, 1891.

${ }^{2}$ Ibid., 25-26, 27-28. 
ple to meet attendant crises. The address was prophetic in recognizing that the United States was entering a new era: that the dynamic forces of modern science and technology, forming an increasingly interdependent society, would require sweeping changes in the nature of education. Some of the changes that McNaughton proposed may be open to question, but he was clearly correct in saying that the schools must modernize their methods, purposes, and programs if they were to respond adequately to the demands and pressures of the new industrial-urban civilization.

McNaughton's call to action had little immediate effect in Iowa where the impact of industrialization was only beginning to be felt. Newly settled, with only forty-three years of statehood by 1890 , predominantly agricultural and rural, Iowa's principal educational problem had been to provide enough schoolhouses and teachers to meet the needs of the waves of settlers who swept across the state between 1850 and 1890. Iowa's school-age population, defined by the state to include everyone between the ages of five and twenty-one, grew from 20,922 in 1847 , the first full year of statehood, to 649,606 in 1889 ; the number of teachers, from 124 to 25,793 ; the number of schoolhouses, from 387 to 12,879 ; and the total cost of operating and maintaining the schools, from $\$ 44,738$ to $\$ 6,848,128 .^{3}$

Iowa's schools were predominantly public, rural, and elementary in 1889. In Iowa as in other states, the growth of nineteenth-century democracy had established the principle that the public must give all children an equal opportunity to achieve an education. Although the actuality of public education fell far short of the ideal, public schools had become the backbone of elementary and secondary education in Iowa by 1889 . There were in the state at the time only 180 private schools attended by 25,440 students. ${ }^{4}$

Of the 12,879 public schools in Iowa, 12,088 were ungraded and 791 were graded. The former were primarily one-room

${ }^{3}$ Biennial Report of the Iowa State Superintendent of Public Instruction, 1888-1889, Twenty-third Iowa General Assembly Documents, 2 (Des Moines, 1889): 14-15. Hereafter cited as Biennial Report, IaSPI, 1888-1889.

${ }^{4}$ Ibid., 11. 


\section{The Annals of Iowa}

country schools, while the latter were mainly town and city schools. In the ungraded schools, the pupils were lumped together under one teacher with little regard to age, ability, or attainment. The curricula of the rural schools presumably included all of the rudiments of learning, but their programs were loosely structured at best, depending largely on the ability and initiative of the teacher. In the graded schools, children generally were classified according to age and organized into eight elementary and intermediate grades, each comprising a year's work for the average child. ${ }^{5}$

The graded systems of the cities and larger towns also included high schools, reflecting the growing popular belief that a system of public education ought to provide more advanced work than that offered by the common schools. It is difficult to tell how many high schools there were in Iowa at the time, for there was no agreement as to what constituted a high school. Henry Sabin, the State Superintendent of Public Instruction, estimated in 1889 that Iowa had "something over" 120 high schools, "which afford instruction in more advanced branches than are usually taught in district schools." But it is abundantly clear in any case that the vast majority of Iowa youths did not yet have an opportunity to acquire more than an elementary education. ${ }^{6}$

The organization and operation of Iowa's public school system reflected the prevailing belief that the schools must be kept close to the people, politically as well as proximately. The independent district and the district township were the principal units of organization and operation. There were four variations of the independent district in 1889: city, town, village, and rural. In each case, however, the independent district was autonomous and ran its schools as it saw fit through a governing board of local directors. The district township was the civil township organized as a school district and was, at least in principle, a larger and more efficient administrative unit than

${ }^{5}$ Ibid., 8-9, 14, 73-75; also see Appendix, "Graded Schools in 1889," 75-79, for a listing of 235 cities and towns with graded schools.

'Ibid., 69-72; Biennial Report, IaSPI, 1892-1893, Twenty-fifth Iowa General Assembly Documents, 2 (Des Moines, 1894): 25. 
the independent district. However, the difference between the two was more apparent than real, for the district township was divided into subdistricts which generally corresponded in size to the independent rural districts and were largely selfgoverning in practice if not in theory. There were, in addition to the independent districts and district townships, a small number of independent township districts which had no subdivisions but operated as a unit under the direction of a township board of directors elected at large and controlling all of the schools in the township. ${ }^{7}$

The independent district was the oldest of Iowa's three district organizations, originating in the isolation of frontier settlement which required local control. Subject to varying degrees of county and township supervision, the independent district continued to be the basis of school organization in Iowa until 1858 when the General Assembly enacted the framework of a statewide system of public education. The act of 1858 , which laid the foundation of Iowa's public school system, sought to create bigger school districts by organizing civil townships as school districts and by reorganizing existing independent districts as subdistricts of the townships, thereby creating the district township system. $^{8}$

The new districts were to be governed by township boards consisting of subdistrict directors elected by the voters of the subdivisions, one director for each subdistrict, and a president, vice-president, and secretary elected at large by the voters of the township. The township boards were authorized to decide how many schools their districts needed and how long they were to run each year; to establish high schools if necessary; to determine what subjects were to be taught; to employ teachers (although the board might delegate this responsibility to the subdirectors who were to supervise the schools in their respective subdivisions); to supervise the expenditure of school funds; and

${ }^{7}$ Biennial Report, IaSPI, 1888-1889, 55-56, 105, 157-158; Biennial Report, IaSPI, 1892-1893, 112, 183.

${ }^{8}$ Clarence Ray Aurner, History of Education in lowa, 5 vols. (Iowa City: State Historical Society of Iowa, 1914-1920), 1 (1914): chs. 1-4, 14. 


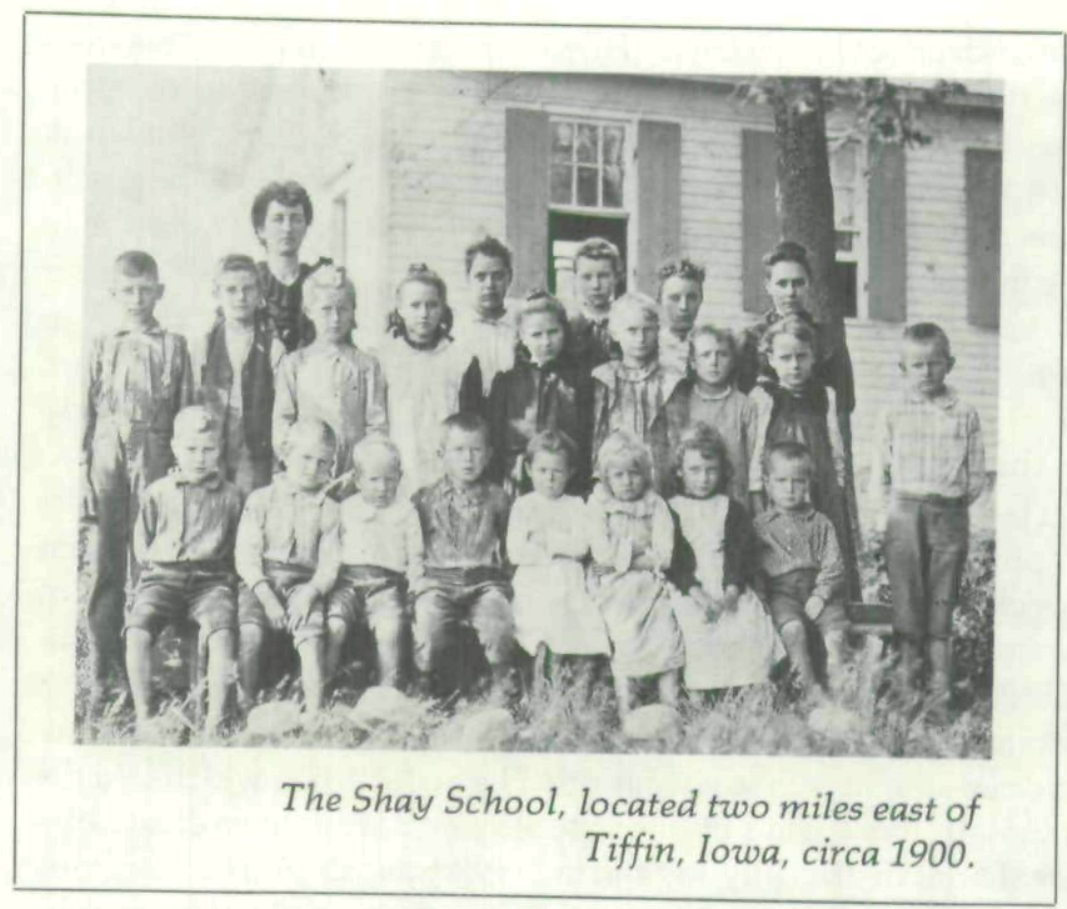

generally to advance the cause of public education in accordance with the law. ${ }^{9}$

The adoption of the district township system failed to settle the vexatious question of school organization. The system was embroiled in controversy from the outset between those who thought that it went too far and those who thought that it did not go far enough. The former called for the restoration of independent districts, complaining of the complexity of the district township system and of its inroad on the traditional freedom of local communities to control their schools without outside interference. The latter urged the abolition of the subdistricts and the adoption of the township district plan, arguing that large unit districts based on civil townships or congressional townships or even counties were more economical and efficient than small districts. ${ }^{10}$

Proponents of independent districts chipped away at the district township system throughout the 1860 s and 70 s. In setting

'Ibid., ch. 15.

${ }^{10} \mathrm{Ibid}$. 
up district townships, the law of 1858 made an exception of incorporated cities and towns with a minimum of 1,000 inhabitants, allowing them to organize independently. The General Assembly extended this privilege to any "city or town" of not less than 300 people in 1862 and to any city, town, or subdistrict of not less than 200 people in 1866 . The General Assembly yielded again to local pressures in 1872, authorizing the restoration of independent districts wherever a majority of the people wanted them. If one-third of the voters of a district township petitioned the board of directors for a referendum on the restoration of independent districts and if a majority of the township voters then agreed to return to the independent plan, the district township was to be dissolved and all of the subdistricts were to be reconstituted as independent districts. ${ }^{11}$

The net effect of the above legislation was to produce a myriad of small school districts. The number of independent districts jumped from 334 in 1870 to 3,451 in 1889 . Some of these districts were urban, but most were rural. The number of district townships remained constant, 1,176 in 1870 and 1,188 in 1889 , but the number of subdistricts increased from 6,986 in 1870 to 8,768 in 1889 . By that time Iowa's public school system had been organized, or disorganized, into 13,407 district townships, subdistricts, and independent districts. ${ }^{12}$

\section{T} power in the hands of state and county officials. The prescribed duties of the State Superintendent of Public Instruction and his lieutenants, the county superintendents, were largely advisory and clerical. The chief function of the state superintendent was to supervise the county superintendents and the common schools of the state. He prepared and published revised editions of the school laws every four years, including all changes made by the General Assembly, and distributed them to school officers; submitted biennial reports to the governor and General

${ }^{11}$ Ibid., chs. 15, 16.

${ }^{12} \mathrm{Ibid} .$, ch. 16; Biennial Report, IaSPI, 1888-1889, 8, 14. 
Assembly, summarizing the statistical reports of the county superintendents and offering his own comments and recommendations for improving the school system; called meetings of the county superintendents to discuss school laws in order to achieve more efficient and uniform administration of the laws; supervised the organization and operation of the teachers' institutes which all county superintendents were required to hold each year; interpreted school law when school officials requested his opinion; and decided cases appealed from the county superintendents involving disputes over such questions as the location of schoolhouses and changes in district boundaries. ${ }^{13}$

The state superintendent also had a number of ex-officio responsibilities. He was the president of the board of directors of the State Normal School in Cedar Falls, a member of the board of regents of the State University in Iowa City, president of the State Board of Examiners, and a trustee of the State Library. ${ }^{14}$

Assisted only by a deputy superintendent, state superintendents complained that the great volume of routine office work allowed them no time to inspect schools or to visit county superintendents in order to gain firsthand knowledge of school conditions. But the chief weakness of the state superintendency was lack of power. Richard C. Barrett, who served three terms as state superintendent (1898-1904), thought that the supervisory powers of the state superintendent were meaningless because he had no legal authority to implement them. The state superintendent published the school laws, but he had no power to execute them. He decided appeal cases and interpreted school law on request, but his judgments could not be enforced until they had been reviewed and upheld by the courts. He issued a variety of instructions to county superintendents and local school boards, but he could not compel either set of officials to obey them. Superintendent F. J. Sessions of East Waterloo aptly

${ }^{13}$ Aurner, 2 (1914): chs. 1-4; Biennial Report, IaSPI, 1888-1889, 51; Biennial Report, IaSPI, 1892-1893, 129, 135; John Purcell Street, "Iowa Department of Public Instruction: Its Origin and Development," Annals of Iowa, Third Series, 30 (October, 1950): 397-398, 404-405, 407-408.

${ }^{14}$ Biennial Report, IaSPI, 1892-1893, 129. 
compared the position of the state superintendent to that of the Continental Congress under the Articles of Confederation. "He can advise anything," Sessions observed, "but can command nothing save a few reports." 15

Despite the limitations of their office, the state superintendents were influential leaders. They were generally able men with a wide range of experience as teachers, principals, city superintendents, and county superintendents. They knew a good deal about the strengths and weaknesses of Iowa's public schools and the improvements that needed to be made. Their proposals were not binding on local officials, but the latter frequently adopted the superintendents' recommendations because they met felt needs. Thus, the state superintendents urged county superintendents not to issue teachers' certificates to girls under seventeen or boys under nineteen, arguing that few persons under these ages possessed the "maturity of mind, the ripe judgment, and the accurate scholarship" necessary for good teaching. They improved the programs of the teachers' institutes by preparing graded courses of study and guidelines for the management of the institutes. They introduced needed uniformity into the examination and certification of teachers by formulating questions in arithmetic, "didactics," geography, grammar, orthography, penmanship, physiology, reading, and United States history for the monthly examinations that county superintendents must give to all applicants for teachers' certificates. They attempted to bring order to the chaos of rural education by preparing and distributing to county superintendents and rural school boards a course of study designed to meet the needs of country schools. ${ }^{16}$

The county superintendents were the chief assistants of the

${ }^{15}$ Ibid., 129-130; Biennial Report of the Iowa Department of Public Instruction, 1898-1899, Twenty-eighth Iowa General Assembly Documents, 2 (Des Moines, 1900): 25-26. Hereafter cited as Biennial Report, IaDPI, 1898-1899; Proceedings, IaSTA, Forty-first Annual Session, December 31, 1895-January 2, 1896, (Des Moines: F. R. Conaway, 1896), 37, 69.

${ }^{16}$ Street, "Iowa Department of Public Instruction," 405-407, 409-416; Biennial Report, IaSPI, 1888-1889, 57, 66-68, 121-122; Biennial Report, IaSPI, 1892-1893, 24, 46, 47, 48-52, 67-71. 


\section{The Annals of Iowa}

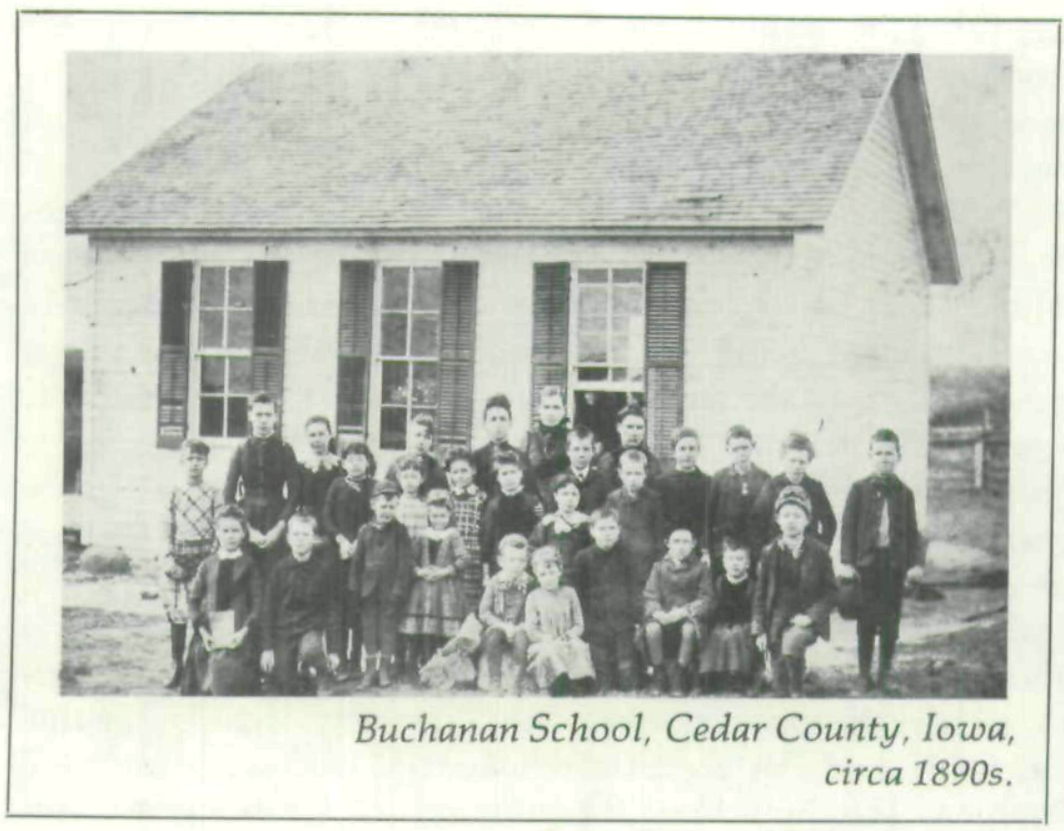

state superintendent and the chief administrators of the counties' educational functions and responsibilities. Although the county superintendent operated on a smaller stage than the state superintendent, his position was relatively as difficult as that of his superior. Standing between the state superintendent and the county voters who elected him, exposed to criticism and pressure from both sides, burdened with more duties than he had time or power to carry out, the county superintendent had one of the hardest jobs in the public school system. "An Iowa county contains about 550 square miles-employs nearly 200 teachers - has from 100 to 300 school officials - and from 4,000 to 8,000 children of school age," noted Superintendent F. J. Sessions of East Waterloo. "The county superintendent who can keep his hand on all of these school interests and direct them properly must have a hand like that of Providence."17

The county superintendency originated in 1858. It was an integral part of the General Assembly's effort to define the roles of state, county, and township in governing the new public

${ }^{17}$ Proceedings, IaSTA, December 31, 1895-January 2, 1896, 33-34, 37. 
school system; it was intended to bridge the gulf between the state superintendent and district school boards and teachers, and to make the certification and supervision of teachers a county function. The county superintendent was to administer the instructions and directions that the state superintendent issued for the guidance and regulation of local school officials and teachers. He was to keep the state superintendent informed of local school conditions through annual reports, which were to include the number of schools, students, and teachers in each district of the county, the cost of maintaining and operating the schools, recommendations for improvement, and any other pertinent matters. ${ }^{18}$

The Education Act of 1858 empowered the county superintendents to examine those who wanted to teach, to license those who were qualified, and to verify their ability to teach by inspecting every school in the county twice a year. Only persons holding a certificate of qualification were eligible to teach in the public schools of Iowa. Candidates were examined on their knowledge of the "common branches" of learning, defined by law as arithmetic, English grammar, geography, orthography, reading, writing, "and such other branches as may be required hereafter." Those who passed the examination and were judged to be of good moral character were licensed. Revocation of license was possible if the county superintendent determined, upon inspection of a school, that the teacher was incompetent. ${ }^{19}$

OPPOSITION to the county superintendency and the changes it implied was intense. Bills were introduced into the General Assembly in 1872,1878 , and 1880 to abolish the office or to cripple it by reducing the superintendents' already meager salary and forbidding them to inspect schools. None of these bills became law, but they were symptomatic of the distrust and

${ }^{18}$ Aurner, 2: 64-66; Jay J. Sherman, "History of the Office of County Superintendent of Schools in Iowa," Iowa Journal of History and Politics, 21 (January, 1923): 12-21, 28-31.

${ }^{19}$ Aurner, 1: 297-298; Aurner, 2: 64-65; Sherman, 28-30. 


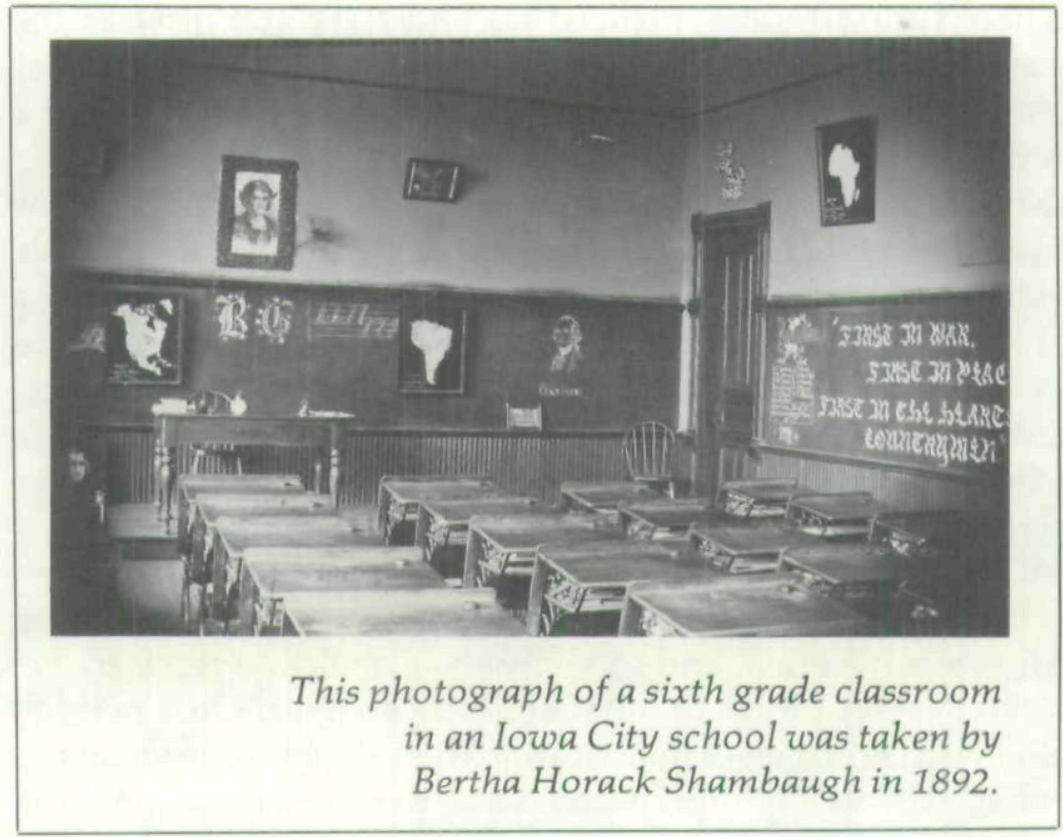

suspicion which dogged the footsteps of county superintendents until the turn of the century. ${ }^{20}$

The public was not yet generally aware of the importance of school supervision. Questions of expense posed serious roadblocks, but opposition centered on the threat of outside interference in local affairs. Many feared that centralization of power in the hands of county superintendents and district township boards would remove control of the schools from the hands of the local community. The disposition of many county superintendents to favor the establishment of township districts only intensified the reservations of those who viewed independent districts as a bastion of local self-government in a democratic society. "We are so intensely republican that the specter of the man on horseback is forever galloping over our liberties," John W. Cook, president of the Illinois State Normal University, remarked in addressing the Iowa State Teachers' Association in $1894 .{ }^{21}$

${ }^{20}$ Aurner, 2: 79, 81, 83; Biennial Report, IaSPI, 1892-1893, 118.

${ }^{21}$ Aurner, 1: 252-253, 273; Aurner, 2: 68-69, 72-78, 79, 91-92; Sherman, 35, 37-38; Proceedings, IaSTA, Fortieth Annual Session, December 26-28, 1894, 


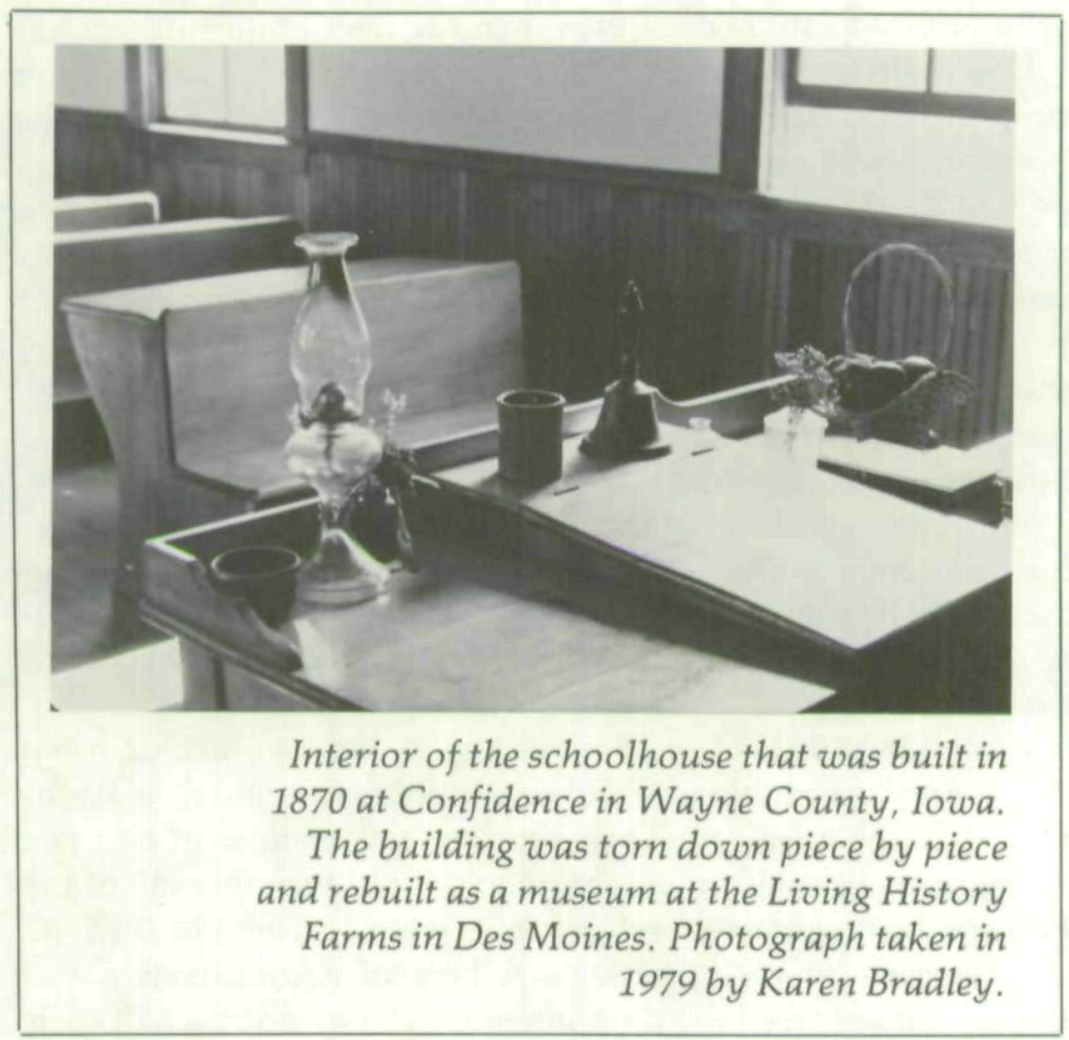

Critics cited the fact that too often the elected county superintendents had no experience or training in education. In setting up the office, the General Assembly had not required specialized experience and training in these officials. Not until 1897 was a law passed specifying that county superintendents must hold a teacher's certificate. Until then, the only requirement of the office was political: anyone who could win nomination and election could be a county superintendent. For such an official to have the power to decide who was qualified to teach was a travesty, argued the critics. They accused the county superintendents of issuing certificates for personal and political reasons and of choosing instructors for the teachers' institutes from among town and village principals who were better known for

(Des Moines: F. R. Conaway, 1895), 37; Proceedings, IaSTA, December 31, 1895-January 2, 1896, 16, 137. 
their ability to influence votes than for their ability to teach. ${ }^{22}$

Educational standards for the office were in fact advocated by proponents of the county superintendency. Persons filling the position ought to have a college or normal school education plus successful teaching experience and they ought to be chosen more carefully, said the reformers. The county superintendents ought to be chosen at special elections, freeing them from the partisan pressures of the biennial general elections; or they should be appointed by county boards of education, by a state agency, such as a board of education, or by the superindent assisted by an advisory board. ${ }^{23}$

Shortcomings of the county superintendents notwithstanding, their partisans insisted that they were doing a better job than the public had any right to expect, given the considerable limitations of their office. They received poor pay (county superintendents were paid a per diem, which the General Assembly fixed at $\$ 2$ in 1862, \$3 in 1866, and \$4 in 1882, until 1902 when the General Assembly established a minimum annual salary of $\$ 1,250$ for the position). Their position was tenuous at best due to frequent elections, brief tenure, and rapid turnover ( 49 of the 99 incumbent county superintendents were unseated in 1894, 41 in 1896, and over 40 in 1898). A host of administrative and clerical duties forced the superintendents to spend much of their time on routine office work instead of visiting schools, helping teachers, holding township meetings, and building public support for the schools. "Certain it is [that] there are few offices requiring such varied talents, so much of sound judgment and wise discretion, with so much of drudgery as that of county superintendent of schools," State Superintendent J. B. Knoepfler observed in $1893 .{ }^{24}$

${ }^{22}$ Aurner, 2: 76-77, 79, 90-91; Sherman, 35, 49, 64, 66; Proceedings, IaSTA, December 30, 1890-January 2, 1891, 68-69; Proceedings, IaSTA, Thirty-ninth Annual Session, December 27-29, 1893, (Des Moines: G. H. Ragsdale, 1894), 15-16, 23; Proceedings, IaSTA, Forty-third Annual Session, December 28-30, 1897, (Des Moines: F. R. Conaway, 1898), 121-122.

${ }^{23}$ Sherman, 66, 87; Proceedings, IaSTA, December 30, 1890-January 2, 1891, 69-70; Proceedings, IaSTA, December 31, 1895-January 2, 1896, 33-34; Biennial Report, IaSPI, 1888-1889, 53; Biennial Report, IaSPI, 1892-1893, 119-120.

${ }^{24}$ Aurner, 2: 70-71, 77-78, 79-80, 81, 84-85, 87, 90; Sherman, 37-38, 49, 68- 
The public gradually accepted the need for county superintendents after it was seen that the functions they performed were indispensable to successful operation of the school system. Superintendent Henry Sabin stated in 1889 that all states had come to recognize the value of the county superintendency; the only question was how to make the office more effective. Declaring that "close supervision" was coming to be "universally" recognized as essential to a well-ordered school system, Sabin reported that the county superintendents of Iowa made 13,418 visits to 10,444 schools in 1889 . They also examined 28,934 applicants for teachers' certificates, issued 25,092 certificates, held 748 educational meetings, conducted ninety-nine county institutes attended by 18,047 teachers, and presided over sixty-five cases appealed from district school boards. Noting that he had been in close contact with most of the county superintendents during the preceding two years, Sabin praised their dedication and industry. "I believe that the large majority of them have devoted themselves to their work with untiring energy, and have displayed a rare fidelity to their trust: an energy and a fidelity worthy the highest commendation," Sabin concluded. ${ }^{25}$

\section{IOWA educators broadened and quickened their efforts to im- prove the state's schools in the 1890s. The public generally had not yet awakened to the need for modernization, but leading educators were well aware that Iowa's schools, still bearing the imprint of their pioneer heritage, were ill prepared to meet the demands of modern industrialism. In analyzing the weaknesses of the schools, the reformers focused most of their attention on six interrelated areas: (1) the need to make the public schools truly public by reaching out to all social classes and achieving}

71; Proceedings, IaSTA, December 26-28, 1894, 77; Proceedings, IaSTA, December 31, 1895-January 2, 1896, 37-38; Biennial Report, IaSPI, 1888-1889, 52; Biennial Report, IaSPI, 1892-1893, 118-121.

${ }^{25}$ Aurner, 2: 86-87, 89-90, 91-92; Sherman, 47-48; Biennial Report, IaSPI, 1888-1889, 11-12, 52-53. 


\section{The Annals of Iowa}

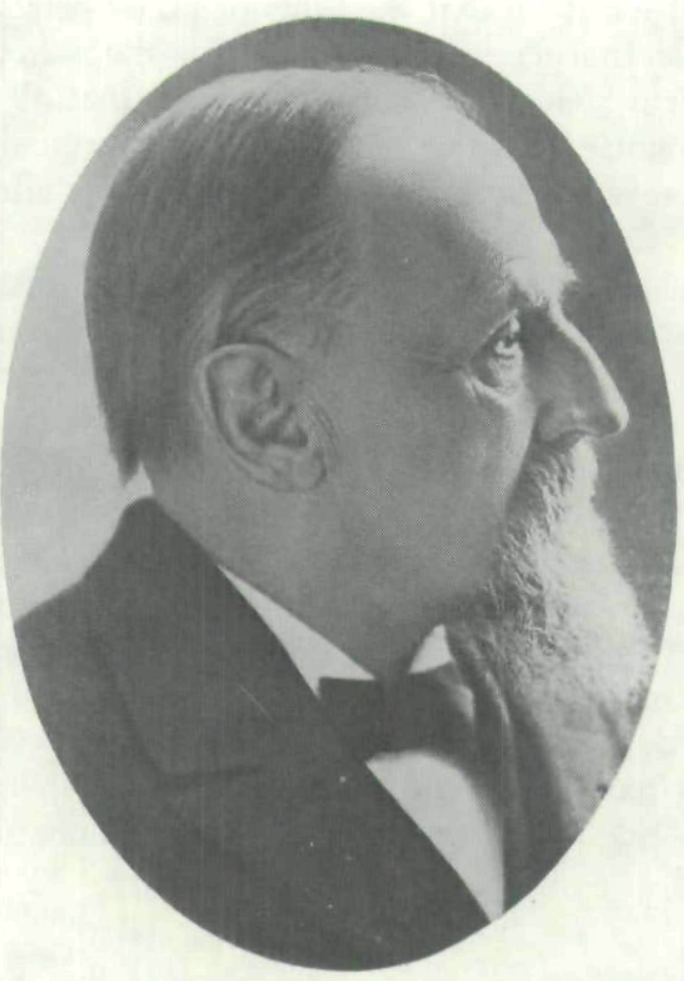

Henry Sabin, State Superintendent of Schools in lowa from 1888-1892 and 1894-1898.

universality in fact as well as in theory; (2) the poor quality of the country schools which offered the only education available to some sixty to seventy percent of the state's children; (3) the glaring shortage of qualified teachers; (4) the fragmentation of the state into thousands of school districts, many of them too small and too weak to be viable; (5) the existence of widespread confusion and uncertainty over the role of the high school and the resulting need to define and systematize the nature and purpose of secondary education; and (6) the presence in all parts of the state of uncomfortable and unsanitary buildings and grounds which endangered the health of school children.

Nineteenth-century Iowans believed that all children, rich and 


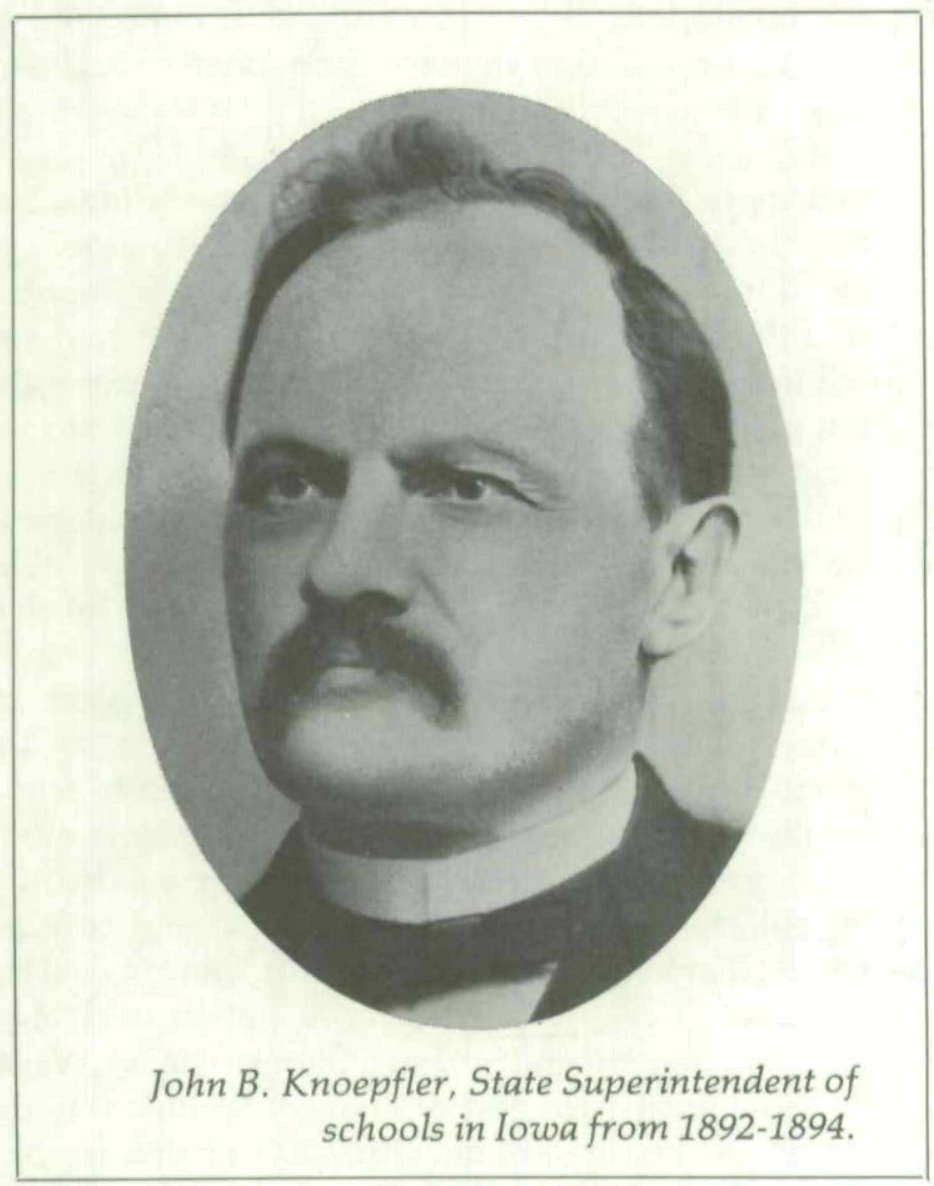

poor alike, ought to have an equal opportunity to obtain an education, but they did not yet equate public education with mass education. Of the 649,606 young people who were included in the enumeration of Iowa's school-age population in 1889 , only 489,229 ( 75 percent) were enrolled in the public schools and only 304,856 (47 percent) attended school. The percentages of enrollment and attendance were even lower in the country schools where distance, bad roads, and the seasonal nature of farming, which permitted older boys to go to school only when winter interrupted the cycle of planting, plowing, and harvesting, all constituted formidable obstacles to regular school attendance. County superintendents estimated that only about sixty 
percent of school-age rural youths were enrolled in school and that only about forty percent went to school often enough to be considered in attendance. ${ }^{26}$

Limited attendance at the public schools was due, in part, to their limited appeal. The schools' curriculums, as the Iowa State Teachers' Association recognized in 1898, were confined "too exclusively to intellectual development" to meet the needs of students and the requirements of society. Courses of study and methods of teaching were largely traditional. The curriculum consisted of academic subjects, and learning consisted of memorizing the textbooks. A few city schools, such as those in Davenport, Des Moines, and Iowa City began to teach domestic science and manual training in the 1890s but industrial training in the schools was still in its infancy and did not have much influence in Iowa until shortly before World War I. ${ }^{27}$

Traditional education was so far removed from the expectations and needs of many farmers and factory workers that they did not consider it worthwhile to send their children to school. Aside from the three R's, they thought that the schools offered little that was useful to those who must labor for a living. One of the principal problems of rural teachers, according to Superintendent A. A. Taylor of Adair County, was "how to deal with big boys who don't see no good [as you put it] in fizology, Grammer, Sivel-Government, and sich things." Henry Wallace thought that the great weakness of country schools was their failure to relate to the life around them. Dismissing textbook knowledge as mostly "cram," Wallace urged country teachers to awaken the minds of their students by teaching them to observe their surroundings and to study the relationship of nature to the life and work of the farmer. ${ }^{28}$

${ }^{26}$ Biennial Report, IaSPI, 1888-1889, 8, 74; Proceedings, IaSTA, December 31, 1895-January 2, 1896, 138.

${ }^{27}$ Proceedings, IaSTA, December 26-28, 1894, 37-41; Proceedings, IaSTA, December 31, 1895-January 2, 1896, 41, 46, 67; Proceedings, IaSTA, Fortyfourth Annual Session, December 27-29, 1898, (Des Moines: F. R. Conaway, 1889), 9, 50, 52; Aurner, 2: ch. 19.

${ }^{28}$ Proceedings, IaSTA, December 26-28, 1894, 70-71, 73-75; Proceedings, IaSTA, December 31, 1895-January 2, 1896, 41, 144-145. (Editor's Note: At the college level lowa was more committed to providing a practical, as opposed to a classical, education. Technical training in agriculture became one 
The limited character of school programs was by no means the only reason, or even the principal reason, why large numbers of children did not go to school. The shortcomings of the schools were essentially the shortcomings of society. School attendance was voluntary: Iowa did not require children to go to school until 1902 and then only for three months. Optional attendance gave free play to a powerful array of hostile economic and social forces over which the schools had no control: parental ignorance and neglect, poverty, public apathy, and the growing demand for child labor in factories, shops, and stores.

How many children were denied an education by the tangled mass of ignorance, indifference, and poverty can only be guessed at, but the number undoubtedly ran into the thousands. Advocates of free textbooks believed that many children did not go to school because their parents were too poor to buy their books. A growing number of educators and laymen, believing that free textbooks were an integral part of free public education, argued that school districts ought to buy textbooks and lend them to children without charge. Declaring that experience had shown that such a policy tended to equalize opportunity and to promote attendance as much as ten percent, the reformers cited the case of Minnesota where provision for free textbooks had increased daily attendance nine percent. ${ }^{29}$

Poverty also contributed to the growth of child labor which deprived numerous children of their educational heritage. Of 96,392 children eight to sixteen years old in Iowa cities of 1,000 or more people in $1889,13,077$ did not attend school and 6,740 worked in factories, shops, and stores. For the state as a whole, the number of children ten to fifteen years old employed in agriculture, domestic and personal service, manufacturing, professional service, and trade and transportation, grew from 20,294 in $1880(17,832$ boys and 2,462 girls $)$ to 29,410 in $1900(24,564$

of the most important courses offered at the Iowa State Agricultural College in Ames in the 1890s. See "An Academic Controversy . . . ," by Edward A. Goedeken on pp. $110-122$ of this issue.)

${ }^{29}$ Biennial Report, IaSPI, 1888-1889, 74; Proceedings, IaSTA, December 2628, 1894, 35-36, 67, 68-69; Proceedings, IaSTA, December 31, 1895-January 2, 1896, 32; Proceedings, IaSTA, December 28-30, 1897, 25; Proceedings, IaSTA, December 27-29, 1898, 50. 
boys and 4,846 girls). Most of these children had little, if any, opportunity for schooling. Charles F. Wennerstrum, the Commissioner of the Iowa Bureau of Labor Statistics (1900-1902), reported that a number of the children whom he encountered in his inspection of factories and shops had never gone to school and that others had attended only a short time and had little knowledge of books. ${ }^{30}$

The educational opportunities of rural children were even more limited than those of urban children. In his presidential address to the Iowa State Teachers' Association in 1898, Amos N. Currier, acting president of the University of Iowa, expressed the consensus of lowa educators when he described the country schools as "the weakest, the most poorly equipped, and the most inefficient corps of our army of education." In his report to the General Assembly in 1889, Superintendent Henry Sabin, Iowa's leading apostle of rural education, stressed the need to offer country children the same educational advantages and opportunities as their more favored city cousins enjoyed. "The problem of what to do for our country schools is a very weighty one and involves many perplexing problems," Sabin emphasized. "It is by far the most urgent one to which the attention of the legislature is invited in this report, and I ask for it the careful consideration which its importance deserves. No other question ought to be allowed to overshadow it." ${ }^{31}$

The growing imbalance between rural and urban education was by no means peculiar to Iowa. The plight of country schools, as Sabin and other Iowa educators recognized, was a nationwide problem growing out of the rapid industrialization and urbanization of American society. In Iowa, the mechanization of agriculture which increased the size of farms and reduced the number of farmers and farm laborers, the movement

${ }^{30}$ Biennial Report, IaSPI, 1888-1889, 97-101; United States Bureau of the Census, Special Reports: Occupations at the Twelfth Census (Washington, 1904), cxxix, cxLviii, cLii-cLiii; Ninth Biennial Report of the Iowa Bureau of Labor Statistics, 4 (Des Moines, 1901): 20-22. Hereafter cited as IaBLS; Keach Johnson, "Iowa's Industrial Roots: Some Social and Political Problems," Annals of Iowa, Third Series, 44 (Spring, 1978): 267-271.

${ }^{31}$ Aurner, 1: 118-120; Biennial Report, IaSPI, 1888-1889, 74-75; Proceedings, IaSTA, December 27-29, 1898, 13. 
of people from the country to cities and towns (including prosperous farmers seeking better educational opportunities for their children), the limited resources of many independent rural school districts, and the frequent indifference of rural communities ("intellectual anemia," to use Currier's description) combined to aggravate the problems plaguing Iowa schools generally: bad housing, meager equipment, poor teaching, and inadequate supervision. ${ }^{32}$

The most visible of these problems was the wretched condition of many rural schoolhouses. Some Iowans were beginning to understand the importance of building schoolhouses that were attractive, clean, and comfortable, but in Iowa, as in other states, the awakening was largely urban and had not yet had much effect on rural school architecture. Critics accused Iowa farmers of giving more thought to the location, shape, and size of their barns than to the attractiveness, comfort, and sanitation of their schoolhouses. "Any kind of building that would keep out the rain in summer, the snow in winter, and would keep the children safely and securely corralled from 9 A.M. to 4 P.M. was good enough for a schoolhouse," Dr. J. W. Mclean of Fayette remarked in presenting a paper on the proper heating, lighting, and ventilation of rural schools to the Iowa State Teachers' Association. Henry Sabin was even more caustic. "All over the state are [rural] school grounds, bare, dreary, and desolate, without a tree to shelter the children from the winter's blast or the summer's sun," Sabin fumed. "Schoolhouses illventilated, unattractive, and repulsive. Outhouses with doors off the hinges, clapboards off the sides, defiled and defaced, a disgrace to a civilized community." ${ }^{\prime 3}$

Many country schools were even less attractive intellectually than they were physically. Dictionaries, globes, maps, and supplementary reading materials were generally available in city

${ }^{32}$ Biennial Report, IaSPI, 1888-1889, 75; Proceedings, IaSTA, December 27-29, 1893, 76-78; Proceedings, IaSTA, December 26-28, 1894, 70-71, $138-$ 143; Proceedings, IaSTA, December 27-29, 1898, 13; Biennial Report, IaDPI, 1904-1905, Thirty-first Iowa General Assembly Documents, vol. 5, pt. 2 (Des Moines, 1906): 120.

${ }^{33}$ Proceedings, IaSTA, December 28-30, 1897, 129-131; Proceedings, IaSTA, December 27-29, 1898, 13, 125. 
schools but generally missing in rural schools. City teachers generally were experienced and relatively well trained graduates of colleges, universities, and normal schools, or of high schools with teacher-training programs. Country teachers generally were inexperienced and untrained, often immature boys and girls with no more than a grade-school education and no professional training beyond that offered by the county institute. City teachers could turn to their supervisors for help, but the isolated rural teachers had to sink or swim alone. Supervision was close and systematic in the city schools but remote and haphazard in the country schools. City superintendents and principals, aided by assistants in the larger cities, were able to visit teachers almost daily, whereas county superintendents, picking their way over miles of tortuous country roads to visit from sixty (the smallest number of teachers in any lowa county in 1893) to several hundred teachers scattered over several hundred square miles, were able to reach each teacher no more often than once or twice a year at most. ${ }^{34}$

Teachers in the cities enjoyed more permanence and stability than those in the country. Cities generally hired teachers for the full school year and re-employed those who were successful year after year. Most rural schools hired teachers one term at a time, frequently employing two or three different teachers during the school year. "It is no uncommon thing to find [rural] schools employing an inexperienced teacher for the fall term, another for the winter and a third for the spring," State Superintendent John B. Knoepfler reported in 1893. The disruptive effects of such hiring practices kept many country schools in a constant state of flux; a teacher hardly had time to get settled, become acquainted with her students, and classify them according to their abilities and needs before a new teacher moved in and the breaking-in process had to be repeated. "The wonder should not be that so little is accomplished [under these circum-

${ }^{34}$ Biennial Report, IaSPI, 1888-1889, 74-75, 172, 186; Biennial Report, IaSPI, 1892-1893, 118-121; Proceedings, IaSTA, December 30, 1890-January 2, 1891, 65, 68, 144; Proceedings, IaSTA, December 28-30, 1897, 25, 121-122; Proceedings, IaSTA, December 27-29, 1898, 51-52; Biennial Report, IaDPI, 19041905, pt. 2: 116-119. 
stances], but that anything is accomplished," Knoepfler commented. ${ }^{35}$

The amount of schooling available to Iowa children was greater in the cities than in the country. The school year was substantially longer in cities and towns than in the country, sometimes by as much as three months. In the school year 19031904, for example, eighty-seven percent of the city and town schools were in session nine months or longer, whereas only nineteen percent of the rural schools operated as long as nine months. Superintendent H. L. Coffeen of Winneshiek County reported in 1895 that the annual attendance of Iowa school children averaged four and one-ninth months per pupil in cities and towns and one and three-fifths months per pupil in the country. The average school life of Iowa children, according to Coffeen, was sixty-six months for those residing in cities and towns and less than twenty-six months for those living in the country. ${ }^{36}$

Many rural youths derived little benefit from their school experience. Coffeen thought that few children attending country schools ("not one pupil in fifty") were well enough prepared when they finished to do high school work. Superintendent L. B. Parshall of Jackson County was even more pessimistic, believing that many if not most of the young people going through the rural schools were no more than nominally literate when they finished. Parshall stated that less than fifty percent of the pupils in country schools could write legibly when they left school. Less than ten percent could "punctuate, capitalize and paragraph fairly;" less than ten percent could "read intelligibly, so as to be readily understood without conscious effort, by the casual visitor at the school;" and less than five percent left school "with a habit of speaking good English." ${ }^{37}$

This is the first of a two-part article. Part II will appear in the next issue of The Annals.

${ }^{35}$ Biennial Report, IaSPI, 1892-1893, 23; Biennial Report, IaDPI, 1904-1905, pt. 2: 112, 117, 118. Only thirty-four percent of the rural schools employed the same teacher throughout the school year, 1903-1904.

${ }^{36}$ Biennial Report, IaDPI, 1904-1905, pt. 2: 118-119; Proceedings, IaSTA, December 31, 1895-January 2, 1896, 59.

${ }^{37}$ Proceedings, IaSTA, December 31, 1895-January 2, 1896, 56-58, 60, 138. 
Copyright of Annals of Iowa is the property of State of Iowa, by \& through the State Historical Society of Iowa and its content may not be copied or emailed to multiple sites or posted to a listserv without the copyright holder's express written permission. However, users may print, download, or email articles for individual use. 